Актуальные вопросы научно-методического обеспечения обучающих программ по теме лесного карантина

Т.И. Морозова, Н.С. Бережная

ФГБУ «Иркутская межобластная ветеринарная лаборатория», ti.morozova@mail.ru

\title{
Current issues of scientific and methodological support of training programs on forest quarantine
}

T.I. Morozova, N.S. Berezhnaya

FSBI “Irkutsk Interregional Veterinary Laboratory”, ti.morozova@mail.ru

\section{Аннотация}

Обосновывается целесообразность организации курсов повышения квалификации в области карантина растений, в частности, в сфере вопросов лесного карантина. Разработана концепция подачи лекционного и практического материала по теме «Лесной карантин» слушателям Федеральной службы по ветеринарному и фитосанитарному надзору. Освещение теоретических вопросов лесного карантина, как составной части всей системы карантина растений. Учтен опыт практической работы и применения нормативной базы при вывозе и экспорте лесоматериалов в Иркутской области, как в самом крупном лесовывозящем регионе Российской Федерации. Основной целью при проведении курсов было получение слушателями комплексных научно-практических знаний и навыков по тематике лесная фитопатология (грибы, бактерии, нематоды), энтомология (вредители лесных насаждений).

Учитывая объемы перемещения лесопродукции как на территории нашей страны, так и в рамках международной торговли, становится ясной и актуальной задача углубленной подготовки специалистов Федеральной службы по ветеринарному и фитосанитарному надзору в области лесного карантина и референтных лабораторий. С задачами обеспечения лесного карантина специалисты Россельхознадзора сталкиваются при первичном исследовании экспортируемой древесной продукции, а также при ее экспорте за пределы страны и при ввозе на территорию российских регионов. Лесоматериалы и конечная продукция из древесины остаются одними из важнейших экспортных товаров России. Советский Союз и, соответственно, Российская Федерация как его приемник, всегда являлись надежным и недорогим поставщиком лесопродукции на мировом рынке. Основными потребителями российских лесоматериалов в настоящее время являются Китай, Япония и Финляндия. Кроме того, значительная часть вывозится в Прибалтику, а затем через морские порты отправляется в другие страны. Среди СНГ первенствуют Узбекистан, Казахстан, Таджикистан, Азербайджан.

В середине 1980-х гг. Европейская и Средиземноморская организация по карантину и защите растений (ЕОКЗР) начала разрабатывать фитосанитарные правила в международной торговле не только по отношению к сельскохозяйственной продукции, посевному и посадочному материалу, но также к древесине и пиломатериалам. Сначала ограничения касались только некоторых вредителей и возбудителей заболеваний древесных пород, отсутствующих в европейском и средиземноморском регионах, затем они распространились на ряд переносчиков возбудителей заболеваний и нематод. В Советском Союзе в 1989 г. в составе Пограничной Государственной инспекции по_карантину растений_была создана служба лесного карантина с целью обеспечения контроля над экспортной древесиной в местах заготовки и отгрузки леса, а также для усиления охраны территории страны от заноса и распространения опасных видов вредителей. В настоящее время функции лесного карантина исполняет Федеральная служба по ветеринарному и фитосанитарному надзору. 
Возрастающий объем товарооборота регионов в связи с увеличивающимся уровнем международной интеграции требует от специалистов карантина растений все новых знаний по нормативно-правовым и методическим нормам. С 1 июля 2017 г вступили в действие единые карантинные фитосанитарные требования в Евразийском экономическом союзе: «Единый Перечень карантинных объектов Евразийского экономического союза» (Решение Совета Комиссии ЕАЭС от 30.11.2016 № 158); «Единые карантинные фитосанитарные требования, предъявляемые к подкарантинной продукции и подкарантинным объектам на таможенной границе и таможенной территории Союза» (Решение Совета Комиссии ЕАЭС от 30.11.2016 № 157); «Единые правила и нормы обеспечения карантина растений на таможенной территории Союза» (Решение Совета Комиссии ЕАЭС от 30.11.2016 № 159); «Порядок лабораторного обеспечения карантинных фитосанитарных мер» (Решение Коллегии Комиссии ЕАЭС от 10.05.2016 № 41) (http:docs.eaueunion.org/ru-ru).

Лесной карантин - обширная область специализированных профессиональных знаний. Система подготовки специалистов диктуется необходимостью получения слушателями комплексных научно-практических знаний и навыков. Нужна подготовка кадров по повышению квалификации специалистов Федеральной службы по профилю лесного карантина. Программа курсов повышения квалификации направлена, прежде всего, на совершенствование профессиональной компетенции специалистов, на освоение современной практики, связанной с лесным фитосанитарным карантинным контролем и надзором, с изменениями карантинного законодательства (в связи с вступлением новых требований ЕАЭС). Обучающая программа состоит из вводной части, которая включает информационные блоки, исторический ретроспективный обзор карантина растений в целом и лесного карантина как составной его части, фитосанитарное карантинное состояние территории Российской Федерации, фитосанитарные риски и научно-методическое обеспечение лесного карантина. Основной части, рассматривающей нормативно-правовые аспекты лесного карантина, методы исследования лесоматериалов и лесных насаждений, и практической части по изучению и совершенствованию методов идентификации карантинных и не карантинных видов вредных организмов.

В лекционном материале отражается динамика показателей состояния лесов Российской Федерации. Показана роль ведущих негативных факторов, влияющих на карантинное фитосанитарное состояние лесных насаждений. Отражены масштабы лесохозяйственной деятельности на территории страны и отдельных регионов, современные тенденции развития лесного комплекса и связанные с этим фитосанитарные риски при перемещении продукции. Предоставляется информация о распространении лесных карантинных организмов (насекомых-вредителей) на территории РФ, площадях их распространения и динамике современных ареалов, о возбудителях болезней леса, являющихся карантинными для стран экспортеров Российской древесины, а также карантинными для России видами. Лекции составлены на основе многолетних научных исследованиях специалистов, литературы, методических указаний ВНИИКР по лесному карантину. Рассматриваются закономерности формирования очагов лесных карантинных вредных организмов, освещены проблемы наложения карантинного режима в очагах КВО и буферных зонах. Обзор, касающийся научно-методического обеспечения лесного карантина, освещает теоретические и практические вопросы формирования перечней КВО, проблем анализа оценки фитосанитарного риска тех или иных биологических объектов, создания нормативной базы и разработки способов обнаружения и идентификации инвазивных организмов. При рассмотрении этой проблемы для древесных насаждений следует не ограничиваться лишь проблемой заноса чужеземных видов. Большое значение имеет процесс возможного распространения аборигенных видов по территории нашей страны из одной биогеографической области в другую при внутрироссийских перевозках. Представлена 
ретроспектива заноса и распространения на территорию РФ различных чужеродных представителей энтомологической фауны и наиболее вредоносных видов болезней древесных растений, приводящих к усыханию лесные насаждения страны.

Особое внимание уделяется разъяснению процедуры проведения анализа фитосанитарного риска проникновения на территорию нашей страны чужеродных вредных биологических объектов, поиску рекомендаций по методам борьбы с их распространением и снижению вредоносности, подсчетам экономических затрат на борьбу в случае их распространения. Показаны принципы создания нормативных документов по идентификации фитопатогенных объектов, работе в очагах КВО (СТО, ТУ, ГОСТ). При формировании образовательной программы обучения особое место следует уделять вопросам нормативно-правового сопровождения лесного карантина для недопущения административных правонарушений, а также вопросам оформления карантинной документации. Знание международных соглашений, в рамках которых осуществляется перемещение лесоматериалов при экспорте, реэкспорте, ввозе в российские регионы является основой правового сопровождения деятельности государственных инспекторов карантина растений и специалистов референтных центров. Подробно рассматриваются и разъясняются вступившие в действие с 01.07.2017. нормативно-правовые акты Евразийского экономического Союза. Опытные специалисты Федеральной службы по ветеринарному и фитосанитарному надзору Российской Федерации помогут слушателям разобраться с изменениями нормативноправовой базы лесного карантина, требований к осуществлению государственного фитосанитарного надзора. Новые тенденции диктуют необходимость владения информацией при вступлении в действие единых фитосанитарных требований (мер) в Еразийском экономическом союзе при контроле перемещения лесоматериалов.

Лесные насаждения Иркутской области являются удобным учебным полигоном для проведения практических занятий по лесной энтомологии и фитопатологии. Богатая лесосырьевая база и наличие большого числа отгрузочных площадок дает возможность оценить масштабы и разнообразие видов лесоматериалов, заготавливаемых и отгружаемых из региона. Посещение лесопромышленных площадок позволяет на практике ознакомиться с методами исследования лесоматериалов и отбора образцов. При проведении занятий по идентификации карантинных видов обучение строится по принципу расширения профессионального кругозора в области лесной энтомологии и фитопатологии и требует знания фитосанитарного и экологического риска вредных организмов, географического распространения карантинных видов. Главное в программе курсов - занятия по лесной энтомологии и фитопатологии, поскольку на практике при проведении фитосанитарных экспертиз специалисты карантинных референтных лабораторий зачастую сталкиваются с трудностями при идентификации видов, в том числе и при прохождении регулярных межлабораторных сравнительных испытаний (МСИ) по карантину растений. Идентификация карантинных видов преподается на основе разработанных в ФГБУ «ВНИИКР» стандартов (СТО ВНИИКР) и Методических указаний по идентификации: Методические рекомендации по процедуре осмотра и отбора проб лесоматериалов для лабораторной карантинной фитосанитарной экспертизы, 2013; Карантинные фитосанитарные требования к местам складирования, переработки и хранения лесоматериалов, 2012; СТО ВНИИКР 2.005-2010 «Азиатский усач - Anoplophora glabripennis (Motschulsky); СТО ВНИИКР 6.003-2010 «Сосновая стволовая нематода - Bursaphelenchus xylophilus (Steiner\&Buhrer) Nickle; Методические рекомендации по досмотру древесных упаковочных материалов на наличие сосновой стволовой нематоды - Bursaphelenchus xylophilus, 2012; Методические рекомендации по выявлению и идентификации: ржавчины тополя - Melampsora medusae Thümen, 2015 г; синевы древесины платана - Ceratocystis fimbriata Ellis \& Halsted f.sp., 2015 г.; возбудителей рака стволов и ветвей сосны, вызываемых Atropellis piniphila (Weir) M.L. Lohman \& E.K. Cash и A. pinicola Zeller \& Goodd, 2014 г.; китайского усача - Anoplophora 
chinensis Forster, 2015; ясеневой изумрудной златки - Agrilus planipennis Fairmaire, 2013; полиграфа уссурийского - Polygraphus proximus, 2014 г.; североамериканских видов жуковусачей рода Monochamus: белопятнистый усач, каролинский усач, северо-восточный усач, тупонадкрылый усач, усач-марморатор, усач-мутатор, южный сосновый усач, 2014 г.; сибирского шелкопряда, 2014 г.; большого елового лубоеда, 2014 г.; орегонского соснового короеда, 2014 г.; калифорнийского короеда, 2014 г.; черных хвойных усачей, входящих в Перечень РФ, черного соснового усача - Monochamus galloprovicialis, большого черного елового усача - Monochamus urussovi, малого черного усача - Monochamus sutor, черного бархатно-пятнистого усача - Monochamus saltuarius, черного крапчатого усача - Monochamus impluviatus, черного блестящего усача - Monochamus nitens, 2014 г.; шестизубчатого короеда - Ips calligraphus, 2014 г.; восточного пятизубчатого короеда - Ips grandicollis, 2014 г. и др.

Для подготовки лекционного материала используется богатый опыт ведущих энтомологических и фитопатологических отечественных научных учреждений Сибири Института леса им. В.Н.Сукачева, лаборатории энтомопатологии древесных растений СИФИБР СО РАН и сотрудничество в области исследований лесных экосистем (Баранчиков Ю.Н., 2015 Морозова, 2015; Белова, Морозова, 2018; Морозова, Воронин, 2017, 2018). В процессе обучающего курса по лесному карантину также предусмотрено ознакомление с опытом ведущих научно-исследовательских учреждений, занимающихся проблемами экологии и защиты леса; предоставляются результаты научно-исследовательской работы преподавателей. Особое внимание уделяется сравнению идентификационных признаков карантинных видов насекомых-вредителей и возбудителей болезней, а также сравнению их с не карантинными видами, близкими по признакам, биологии и степени вредоносности. Освещаетсяь видовое разнообразие лесных вредителей и возбудителей болезней по отдельным лесовывозящим регионам страны - в Европейской части страны, в Сибири, на Дальнем Востоке. При изучении насекомых-вредителей в бо́льшей степени следует уделять внимание насекомым-ксилофагам (стволовым вредителям древесины) и заболеваниям леса. Подробно изучались особенности географического распространения и биологии усачей рода Monochamus, внесенных в Список карантинных вредителей, ограниченно распространенных на территории Российской Федерации. При их рассмотрении особое значение имеет знание четких различий сравнительных диагностических признаков с северо-американскими видами этого рода.

На практических занятиях слушатели должны получить навыки определения карантинных видов усачей на различных физиологических стадиях - не только по имаго (взрослым жукам), но и по личинкам, поскольку при исследовании лесоматериалов личинки обнаруживаются в древесине. Кроме того, на практических занятиях слушатели имеют возможность научиться отличать личинок черных хвойных усачей от личинок широко распространенных не карантинных видов (Acanthocinus, Rhagium, Tetropium и др.). В лесных насаждениях Иркутской области выявлено более 200 видов грибов, повреждающих древесину, отмечены бактериальные повреждения древесных и кустарниковых пород. Микологическая и бактериологическая экспертиза наиболее сложна в определении. Учитывая, что большая часть карантинных возбудителей грибных болезней входит в Список I Единого Перечня, который включает виды, отсутствующие на территории ЕАЭС, учебный материал строится на сравнении признаков не карантинных видов фитопатогенных грибов с карантинными видами.

Изучение представителей других экологических групп ксилофагов - короедов, долгоносиков, златок, - также строится по аналогии с изучением усачей, наглядно демонстрируются различия карантинных и не карантинных видов, слушателям предлагается провести определение экземпляров жуков и личинок по характерным отличительным признакам. Особое внимание на занятиях уделяется изучению наиболее вредоносных 
карантинных хвое- и листогрызущих насекомых-вредителей: сибирского шелкопряда, непарного шелкопряда. При подаче учебного материала рассматриваются тенденции расширения современных ареалов этих видов, глобальные и региональные причины этого процесса. На практических лабораторных занятиях слушатели подробно изучают особенности морфологического и анатомического строения бабочек и гусениц. Также освещаются результаты исследований сибирского и непарного шелкопрядов с использованием феромонных ловушек.

На занятиях по фитогельминтологии, посвященных изучению карантинной сосновой стволовой нематоды Bursaphelenchus xylophylus, демонстрируются методы выделения нематод из древесины. На практическом занятии образцы лесоматериалов подвергаются лабораторной экспертизе методом Бермана, выделенные древесные нематоды идентифицируются морфологически под микроскопом. При исследовании образцов древесины имеется возможность изучить близкородственный не карантинный вид Bursaphelenchus mucronatus, распространенный в Иркутской области (Морозова, Ломакин, 2005). По итогам занятий слушатели экзаменуются по основным темам обучения в виде экзамена/зачета и получают свидетельство о прохождении курсов и повышении квалификации. Программа обучения рассчитана на недельный (40 часов учебного времени) и двухнедельный (90 часов) курс.

Разработанные программы по лесному карантину направлены на совершенствование профессиональной компетенции специалистов Федеральной службы по ветеринарному и фитосанитарному надзору, на повышение профессионального уровня в рамках имеющейся квалификации. Специалистами проводится многолетний мониторинг по изучению лесопатологической обстановки в лесах Байкальской Сибири и выявлению карантинных видов. Глубокое знание диагностических признаков карантинных и не карантинных видов, владение стандартными методами их диагностики позволит предотвратить нарушение фитосанитарных требований стран, в которые экспортируются российские лесоматериалы. В связи с недостаточным объемом обследований насаждений мониторингом за карантинными видами, повреждающими лес в Иркутской области, было упущено выявление и идентификации очагов размножения полиграфа уссурийского Polygraphus proximus. Датировка времени поселения была проведена специалистами в Сибирском институте физиологии и биохимии растений методами дендрохронологии.

\section{Список литературы}

Баранчиков Ю.Н., Пашенова Н.В. 2015. Рывок на запад: дальневосточные инвайдеры в лесах и парках России. В кн.: Защита лесов от вредителей и болезней: научные основы, методы и технологии. В кн.: Защита лесов от вредителей и болезней: научные основы, методы и технологии. Материалы Всероссийской научной конференции с международным участием. Иркутск: Издательство Института географии им. В.Б. Сочавы СО РАН: 6-11. Белова Н.А., Морозова Т.И. 2018. Динамика лесопатологического состояния пихтовых древостоев Байкальского заповедника (1983-2015). Вестник МГУЛ-Лесной вестник. 22(2): $5-15$.

Воронин В.И., Морозова Т.И. 2018. Устойчивость темнохвойных лесов Прибайкалья к «новым» болезням. Экология и география растений и растительных сообществ: Материалы IV Международной научной конференции. Екатеринбург. 155-159.

Морозова Т.И., Ломакин А.Н. 2005. Распространение хвойной древесной нематоды в Иркутской области. В кн.: Природная и антропогенная динамика наземных экосистем. Иркутск: Изд-во Иркутского государственного технического университета: 107-110. Морозова Т.И., Воронин В.И., 2018. Многолетний мониторинг состояния лесов Байкальского региона и выявление причин массовых повреждений леса. В сб. А.В. Руоколайнен, А.В. Кикеева (ред.) Проблемы лесной фитопатологии и микологии: материалы X международной 
конференции, посвященной 80-летию со дня рождения д.б.н. Виталия Ивановича Крутова. Петрозаводск: КарНЦ: 115-117.

Морозова Т.И. 2015. Комплекс заболеваний, выявленный на хвойных породах в Байкальской Сибири. В кн.: Защита лесов от вредителей и болезней: научные основы, методы и технологии. Материалы Всероссийской научной конференции с международным участием. Иркутск: Издательство Института географии им. В.Б. Сочавы СО РАН: 68-72.

Морозова Т.И., Воронин В.И. 2017. Мониторинг очагов развития бактериальной водянки в темнохвойных лесах Южного Прибайкалья. В кн.: Эпидемии болезней растений:

мониторинг, прогноз, контроль. Материалы Международной конференции, выпуск 8: 191195. 